\title{
ХАРАКТЕР ТА ОСОБЛИВОСТІ МОРФОЛОГІЧНИХ ЗМІН У ПІДНЕБІННИХ МИГДАЛИКАХ У ХВОРИХ НА ХРОНІЧНИЙ ТОНЗИЛІТ ЗАЛЕЖНО ВІД РІВНЯ АПОПТОЗУ ЛІМФОЦИТІВ
}

\section{○М. І. Герасимюк, О. І. Яшан \\ ДВНЗ «Тернопільський державний медичний університет імені І. Я. Горбачевського МОз України»}

РЕзЮмЕ. При зіставленні стану апоптозу і некрозу в лімфоцитах піднебінних мигдаликів і периферійної крові за результатами морфологічних досліджень у хворих на хронічний тонзиліт встановлено залежність морфологічних змін від стану апоптозу.

Мета дослідження - встановити рівень апоптозу і його співвідношення з некрозом у лімфоцитах і нейтрофілах гомогенату піднебінних мигдаликів та у периферійній крові хворих на хронічний тонзиліт і зіставити отримані дані з результатами морфологічних досліджень.

Матеріал і методи. Проведено обстеження хворих на хронічний тонзиліт після тонзилектомії з визначенням стану апоптозу і некрозу в лімфоцитах та нейтрофілах гомогенату піднебінного мигдалика і у периферійній крові на проточному цитофлюориметрі. Крім того, всім пацієнтам проводилося морфологічне дослідження видалених піднебінних мигдаликів.

Результати. При хронічному тонзиліті в лімфоцитах апоптоз переважає над некрозом. Таке переважання характерне для бактерійного ураження мигдаликів, на відміну від вірусного, при якому воно проявляється у нейтрофілах. Причому кратність цього переважання корелює із морфологічними змінами у самих мигдаликах.

По мірі наростання патоморфологічних змін наростає і кратність співвідношення апоптоз/некроз. При співвідношенні, кратному 2-3, патоморфологічна картина представлена лише помірними судинними реакціями у вигляді посилення васкуляризації із збільшенням кількості та розширенням просвіту дрібних артерій і артеріол 3 одночасним зниженням пропускної спроможності артерій середнього калібру. Це, разом із морфологічним станом слизової оболонки, сполучнотканинної капсули і фолікулів дає підстави вважати, що захворювання ще перебуває у стадії компенсації і підлягає консервативному лікуванню.

При співвідношенні апоптоз/некроз, кратному 4-6, були зареєстровані судинні зміни дилатаційного характеру. До них приєднувалися морфологічні зміни у вигляді стоншання слизової оболонки, потовщення сполучнотканинної капсули і зменшення розмірів фолікулів та їх просвітлення, що, разом із явищами метаплазії і гіперкератозу епітелію слизової оболонки, може бути підтвердженням субкомпенсації патологічного процесу.

Виявлені ж при кратності співвідношення апоптоз/некроз в 7 разів і більше морфологічні зміни у вигляді подальшої деградації епітелію слизової, проліферації сполучної тканини як у капсулі, так і проникнення ії̈ у паренхіму разом із вираженим периваскулярним склерозом, деструктивними змінами із макрофагальною реакцією у значно зменшених за розмірами лімфоїдних фолікулах, наявністю скупчень білкового детриту та відповідними судинними реакціями $є$ ознаками декомпенсації захворювання і необхідності його оперативного лікування.

Висновки. При співвідношенні апоптоз/некроз у лімфоцитах гомогенату піднебінних мигдаликів і периферійній крові, кратному 2-4, морфологічні зміни у самих мигдаликах відповідають захворюванню у стадії компенсації, при співвідношенні 4-6 за даними морфологічних досліджень процес можна вважати субкомпенсованим і при співвідношенні 7 і більше - декомпенсованим.

КлючОВІ СлОВА: тонзиліт; апоптоз; епітелій; метаплазія; склероз.

Вступ. Хронічний тонзиліт (ХT) займає одне з провідних місць за частотою виникнення серед оториноларингологічної нозології. Згідно з даними різних авторів, хронічним тонзилітом страждають від 12,5 \% до 22,1 \% населення, що складає 22-40 \% усієї хронічної ЛОР-патології $[9,6,12]$. Характерними рисами ХТ вважають впертий перебіг з високою ймовірністю розвитку ряду метатонзилярних ускладнень [6, 7]. Крім того, переконливо доведено, що піднебінні мигдалики (ПМ) беруть активну участь у формуванні місцевого та гуморального імунітету $[8,12,13,16]$. Тому серед системних ускладнень найбільшу небезпеку становить поєднана з хронічним тонзилітом імунологічна патологія - гломерулонефрити, ревматизм, васкуліти тощо. Іншими словами, хронічний запальний процес у зоні глоткового лімфоепітелі- ального кільця є постійно діючим джерелом токсичного впливу, що порушує гомеостаз організму. Тому XT необхідно розглядати як осередкову інфекцію, елімінація якої $\epsilon$ виключно важливою частиною збереження здоров'я людини в цілому, а також успішного лікування поєднаних захворювань $[4,2]$. Однак проблема вибору оптимального методу лікування XT і надалі залишається в центрі уваги клініцистів-отоларингологів [9]. Згідно з класифікацією Л. А. Луковського, яку використовують в Україні впродовж десятиліть (1941, 1955, 1966), розрізняють компенсований, субкомпенсований і декомпенсований хронічний тонзиліт. В перших двох стадіях застосовують консервативне лікування, а у стадії декомпенсації методом вибору стає хірургічне втручання [5]. Однак іноді складно провести чітку межу між згаданими стадіями. 
Огляди літератури, оригінальні дослідження, погляд на проблему

Критеріями ефективності консервативної терапії вважають підвищення кількості життєздатних лімфоцитів і зменшення кількості лімфоцитів піднебінних мигдаликів, що перебувають у стані апоптозу, а також зниження вмісту сироваткових IgA та IgM і підвищення концентрації секреторного slgA у складі лакунарного секрету [10].

Водночас відомо, що важливою функцією апоптозу в багатоклітинних організмах $\epsilon$ підтримання клітинного гомеостазу, тобто сталості клітинної популяції. При цьому забезпечується правильне співвідношення чисельності клітин різних типів, селекція різновидів клітин усередині популяції, видалення генетично дефектних клітин [3, $11,15,17]$.

Мета роботи - встановити рівень апоптозу і його співвідношення з некрозом у лімфоцитах $\mathrm{i}$ нейтрофілах гомогенату піднебінних мигдаликів та у периферійній крові хворих, прооперованих з приводу хронічного тонзиліту, а також зіставити отримані дані з результатами морфологічних досліджень.

Матеріал і методи дослідження. Нами проведено обстеження 30 пацієнтів, хворих на хронічний тонзиліт, яким була виконана тонзилектомія 3 наступним визначенням стану апоптозу і некрозу в лімфоцитах та нейтрофілах, отриманих 35 \% гомогенату видаленого піднебінного мигдалика, і в периферійній крові. Дослідження клітин виконували на проточному цитофлуориметрі Epics XL ("Beckman Coulter», USA).

Крім того, всім пацієнтам проводили морфологічне дослідження видалених ПМ. Шматочки тканини мигдалика фіксували у 10 \% розчині нейтрального формаліну, рідині Карнуа і в $96^{\circ}$ спирті.
Парафінові зрізи товщиною 5-8 мкм робили у трьох взаємноперпендикулярних площинах і забарвлювали гематоксиліном та еозином, резорцинфуксином за Вейгертом, а також за Ван Гізон. Для виявлення глікогену застосовували ШЙК-реакцію.

Морфометричну оцінку тканин на гістологічних зрізах здійснювали за допомогою окуляр-мікрометра МОВ-1-15×. При цьому вимірювали діаметр фолікулів, товщину слизової оболонки, кількість шарів епітелію у ній, а також товщину сполучнотканинної капсули мигдалика. Оцінку функціонального стану судин проводили шляхом вирахування IB-індексу Вогенворта [1], тобто відношення площі середнього шару артерій до площі їх просвіту:

$$
\mathrm{IB}=(\mathrm{SM} / \mathrm{S} \Pi \mathrm{p}) 100
$$

де: SM - площа медії, SПр - площа просвіту судини.

Морфометричний аналіз судин проводили на артеріях із зовнішнім діаметром 26-50 мкм. Статистичну обробку отриманих результатів здійснювали методом варіаційної статистики з використанням програми «Microsoft Excel». Визначали середнє значення (М), стандартне відхилення (ठ) та похибку середнього (m).

Результати й обговорення. За результатами проведеного дослідження було встановлено, що в усіх випадках у лімфоцитах гомогенату ПМ апоптоз переважав над некрозом (співвідношення апоптоз/некроз було > 1, причому середня кратність складала $(6,20 \pm 2,06)$ разів, а при згладжуванні варіаційного ряду - $(5,84 \pm 0,76)$ разів). У нейтрофілах - навпаки, некроз переважав над апоптозом (співвідношення: апоптоз/некроз було < 1 - середня кратність лише $(0,65 \pm 0,16)$ раза) (рис. 1).

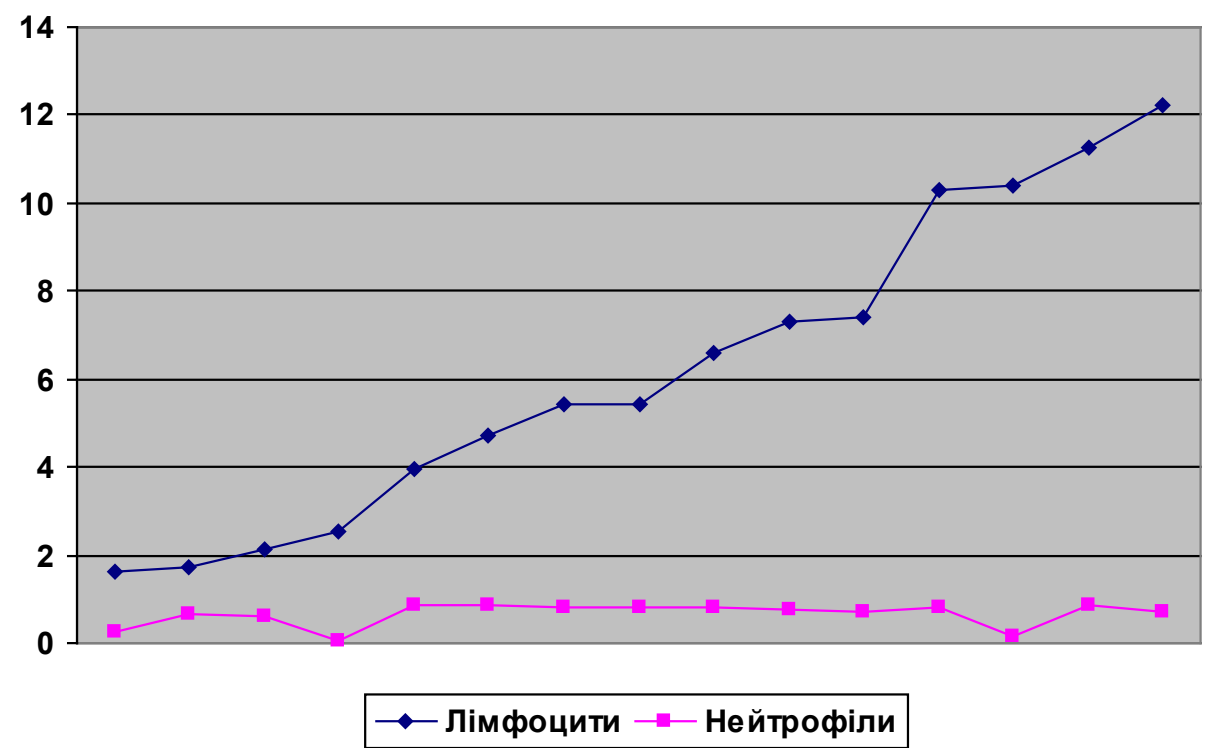

Рис. 1. Діаграма співвідношень апоптозу і некрозу в лімфоцитах і нейтрофілах гомогенату піднебінних мигдаликів у хворих на хронічний тонзиліт. 
Огляди літератури, оригінальні дослідження, погляд на проблему

Співвідношення ж апоптоз/некроз у лімфо- ким же співвідношенням цих показників у перицитах гомогенату також тісно корелювало із та- ферійній крові (рис. 2).

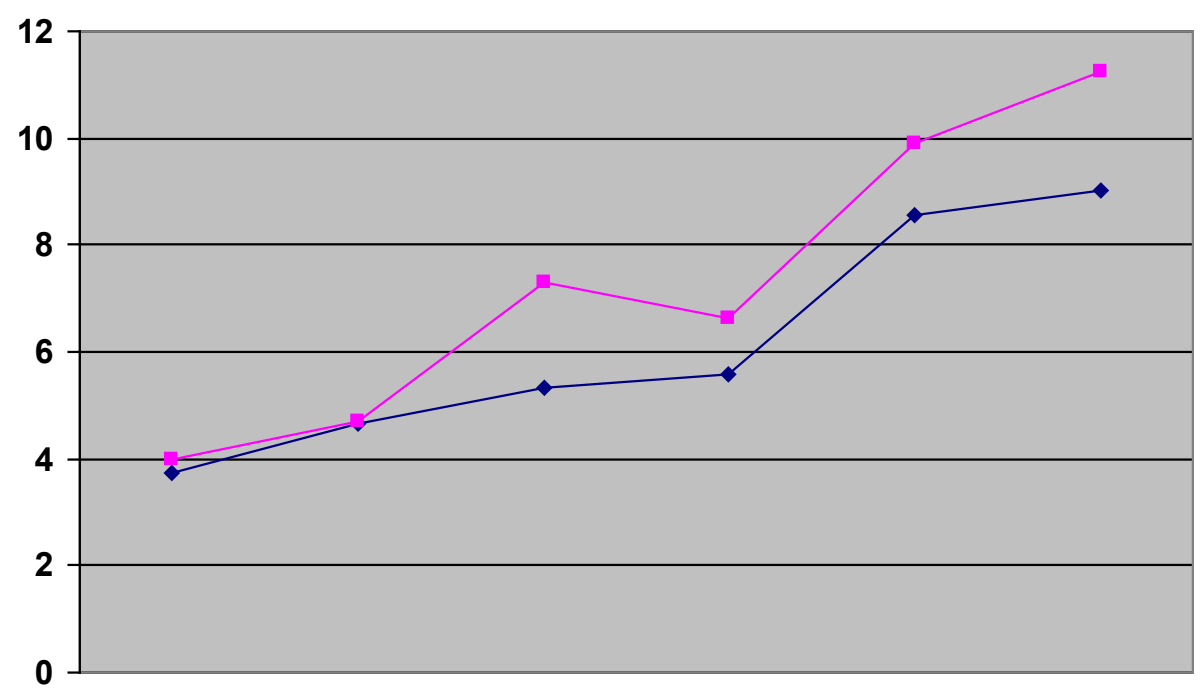

$\rightarrow-$ Лімфоцити крові - -Лімфоцити мигдаликів

Рис. 2. Діаграма співвідношень апоптозу і некрозу в лімфоцитах мигдаликів і в лімфоцитах крові під час оперативного видалення мигдаликів у хворих з хронічним тонзилітом.

При дослідженні гістологічних зрізів ПМ після їх оперативного видалення у хворих з діагнозом: «Хронічний декомпенсований тонзиліт» виявлено наступне. У тих випадках, коли співвідношення апоптоз/некроз було порівняно невисоким (в межах кратності у 2-3 рази) в препаратах чітко візуалізувалася добре виражена слизова оболонка, яка була представлена призматичним біля основи і багатошаровим плоским незроговілим епітелієм у поверхневих шарах (рис. 3), яка досить активно сприймала ШЙК-барвники для виявлення глікогену. Ії̈ середня товщина сягала $(147,67 \pm 3,14)$ мкм. Кількість шарів епітеліальних клітин складала $(18,50 \pm 0,76)$. Власна пластинка слизової заглиблювалася в епітеліальний шар у вигляді численних сосочків. Сполучнотканинна капсула була порівняно нетовстою (ії товщина в середньому складала $(25,17 \pm 1,01)$ мкм) та досить щільною i, по суті, в місцях, де мигдалики не були покриті слизовою, вона продовжувала підслизову основу. В товщі капсули містилися численні судини. Артеріоли і дрібні артерії у більшості виглядали зяючими, без формених елементів крові у просвіті. Стінки артерій середнього калібру були переважно у стані підвищеного тонусу, про що свідчила насиченість їх забарвлення і досить виражена складчастість внутрішньої еластичної мембрани (рис. 4). Індекс Вогенворта при цьому складав $(128,45 \pm 3,75)$. Лімфоїдні фолікули також досить інтенсивно сприймали барвники і мали чіткі межі. Їх розміри перебували в діапазоні діаметрів $(281,83 \pm 14,91)$ мкм.

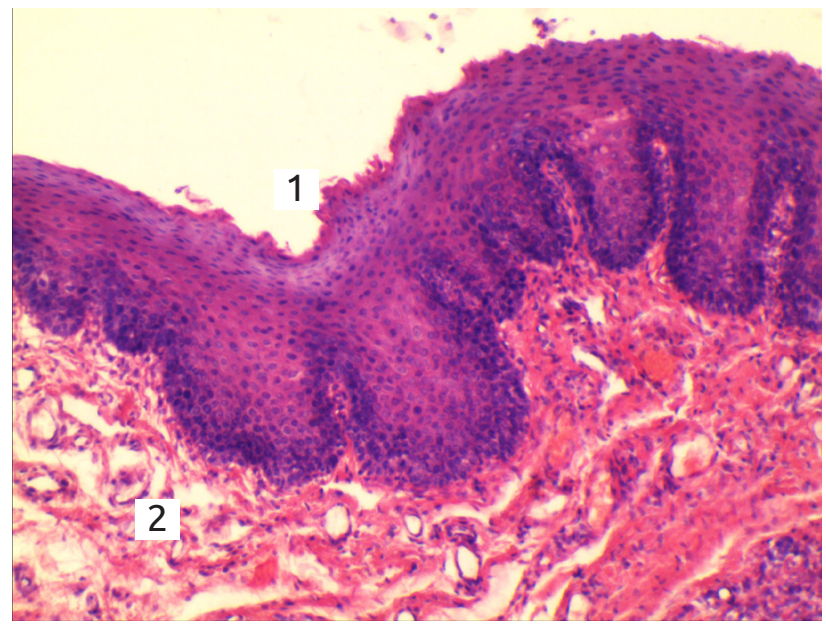

Поверхня слизової оболонки піднебінного мигдалика з поверхнево розміщеним багатошаровим плоским, а біля основи призматичним епітелієм (1), підслизова основа, яка формує сполучнотканинну капсулу мигдалика (2).

Рис. 3. Гістологічний зріз піднебінного мигдалика при співвідношенні апоптоз/некроз в лімфоцитах гомогенату 2,53 (пацієнт № 13). Забарвлення гематоксиліном і еозином. $\mathrm{x} 180$.

У хворих, у яких співвідношення апоптоз/некроз в гомогенаті ПМ було в межах від 4 до 6, при морфологічному дослідженні насамперед звертали на себе увагу судинні реакції. Загальна кількість судин зростала, їх просвіт нерідко був заповнений скупченнями еритроцитів, а стінки перебували у різному функціональному стані: від спазмованих із «гофрованими» внутрішніми еластичними мем- 
Огляди літератури, оригінальні дослідження, погляд на проблему

бранами артерій до зяючих округлої форми судин з набухлим ендотелієм, ядра якого випиналися в просвіт у вигляді «частоколу» (рис. 5). Індекс Вогенворта при цьому в цілому набував тенденції до зниження і складав $(111,38 \pm 5,77)$, що свідчило про переважання дилатаційних реакцій у стінках артерій.

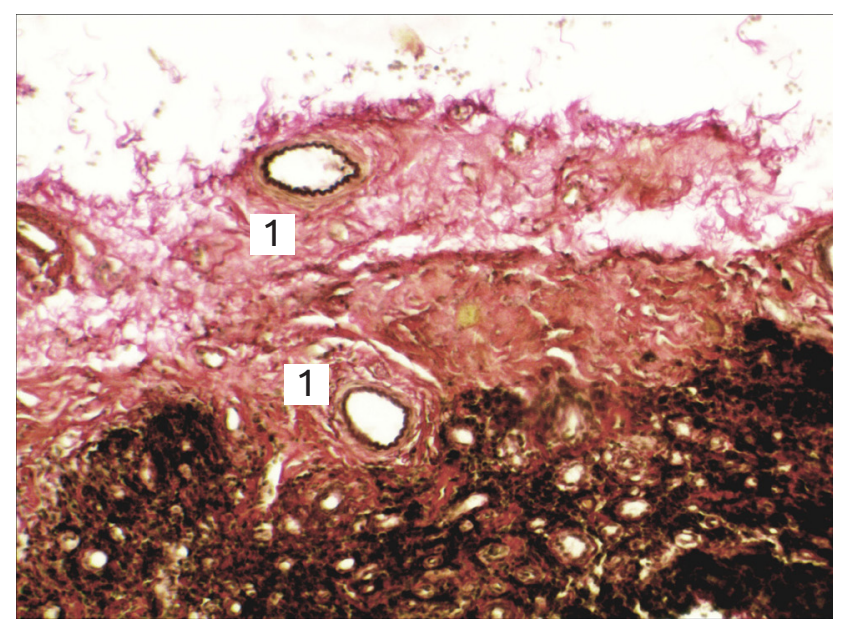

Складчастість внутрішніх еластичних мембран 3 ущільненням стінок артерій середнього калібру (1).

Рис. 4. Гістологічний зріз піднебінного мигдалика при співвідношенні апоптоз/некроз в лімфоцитах гомогенату - 1,64 (пацієнт № 14). Забарвлення за Вейгертом. x 180.

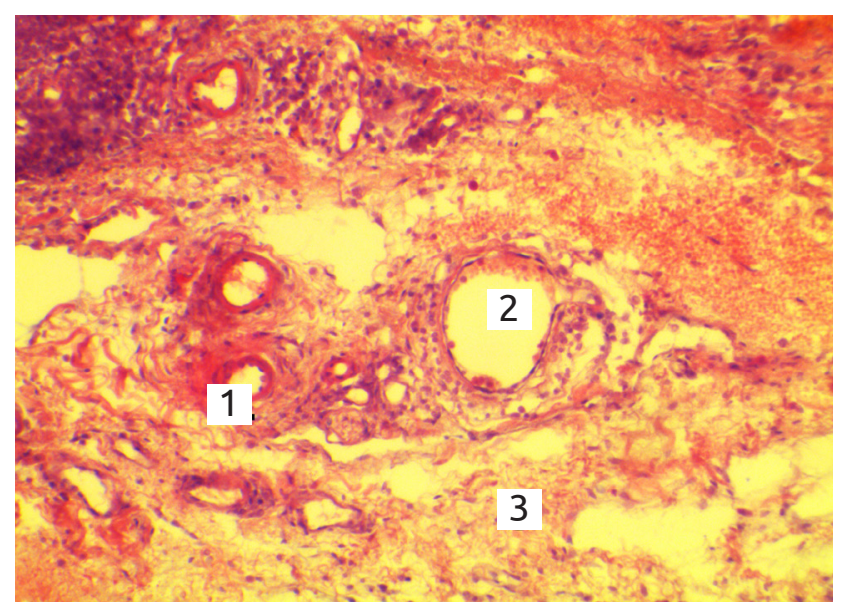

Артерія з ущільненою стінкою і вибуханням ендотелію у просвіт судини у вигляді «частоколу» (1), розтягнутий просвіт вени із сплющеним ендотелієм (2), розпушена за рахунок набряку сполучнотканинна капсула (3).

Рис. 5. Гістологічний зріз піднебінного мигдалика при співвідношенні апоптоз/некроз в лімфоцитах гомогенату 7,42 (пацієнт № 19). Забарвлення гематоксиліном і еозином. $x 180$.

Слизова оболонка стоншувалася до $(104,50 \pm$ $5,74)$ мкм, її призматичний епітелій підлягав метаплазії у плоский, кількість його шарів зменшувалася до $(14,50 \pm 0,76)$, а сполучнотканинна капсула навпаки - потовщувалася до $(66,33 \pm 4,07)$ мкм і розпушувалася. В поверхневих шарах плоского епітелію спостерігався гіперкератоз. Внаслідок розтягування власної пластинки слизової оболонки вона втрачала свої сосочки і вже не заглиблювалася у товщу слизової. Тому межа між ними набувала характеру прямої лінії. Водночас відбувалося просвітлення лімфоїдних фолікулів з їх чіткою диференціацією на тлі інтенсивніше забарвленої дифузної лімфоїдної тканини. Самі фо-

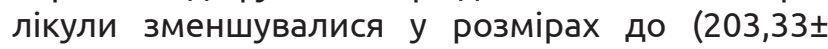
16,37) мкм, знижувалася їх кількість (рис. 6, 7).

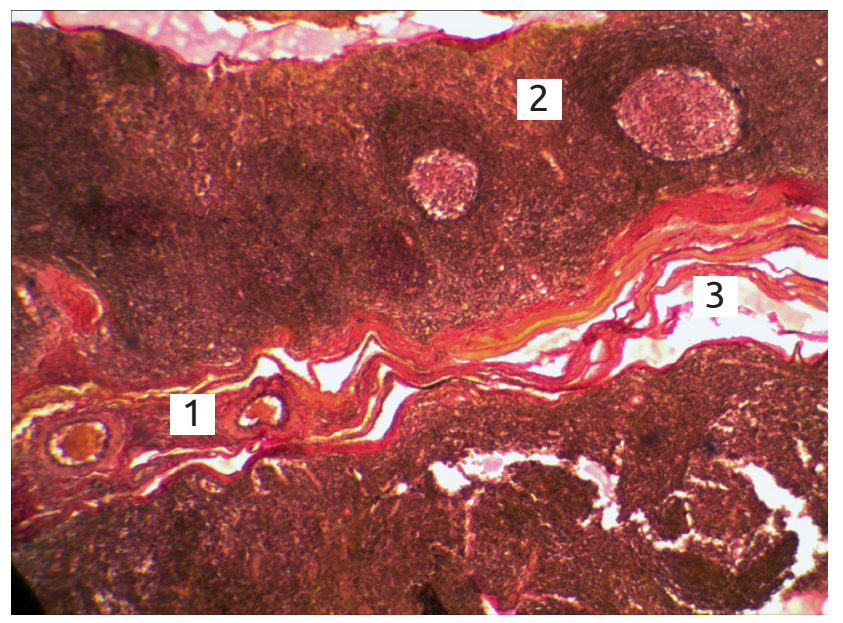

Артерії з різним функціональним станом стінок: від помірно складчастої до гофрованої внутрішньої еластичної мембрани (1), просвітлення і зменшення у розмірах лімфоїдних фолікулів (2), проростання волокон сполучної тканини в паренхіму мигдалика (3).

Рис. 6. Гістологічний зріз піднебінного мигдалика при співвідношенні апоптоз/некроз в лімфоцитах гомогенату - 6,61, у крові - 5,58 (пацієнт № 23). Забарвлення за Вейгертом. х 180.

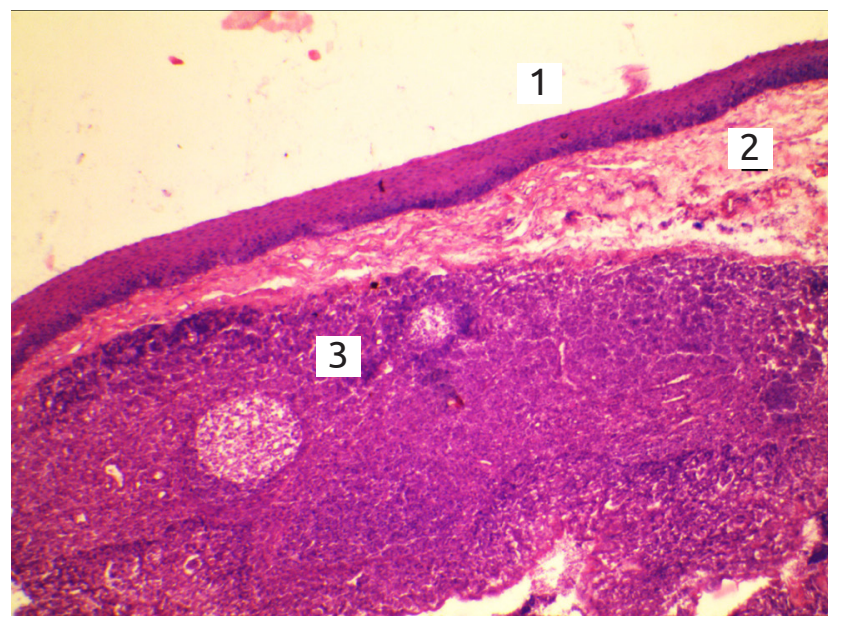

Атрофія і стоншання слизової оболонки із зменшенням кількості її шарів і метаплазією призматичного епітелію у плоский (1), набряк з розпушуванням підслизового шару (2), просвітлення і зменшення розмірів лімфоїдних фолікулів (3).

Рис. 7. Гістологічний зріз піднебінного мигдалика при співвідношенні апоптоз/некроз в лімфоцитах гомогенату 10,39 (пацієнт № 16). Забарвлення гематоксиліном і еозином. $x 180$. 
Огляди літератури, оригінальні дослідження, погляд на проблему

Всі ці явища прогресували по мірі наростання співвідношення апоптоз/некроз від кратності у 7 разів і вище. Розміри фолікулів продовжували зменшуватися до $(164,00 \pm 17,02)$ мкм, слизова стоншувалася до $(73,17 \pm 3,37)$ мкм, кількість шарів епітелію у ній знижувалася до $(10,50 \pm 0,89)$.

Крім того, у цій групі обстежених до описаних процесів приєднувалися зміни склеротичного характеру. Значно потовщувалася сполучнотканинна капсула - до $(109,50 \pm 10,68)$ мкм, а іії відроги глибоко проникали в товщу паренхіми, утворюючи досить помітні прошарки. Вираженим ставав периваскулярний склероз (рис. 8), самі ж судини в усіх полях зору були перерозтягнутими, з округлої форми просвітами, кількість їх зростала, а в просвіті нерідко можна було спостерігати значні скупчення еритроцитів, пристінкові тромби (рис. 9). У ре-

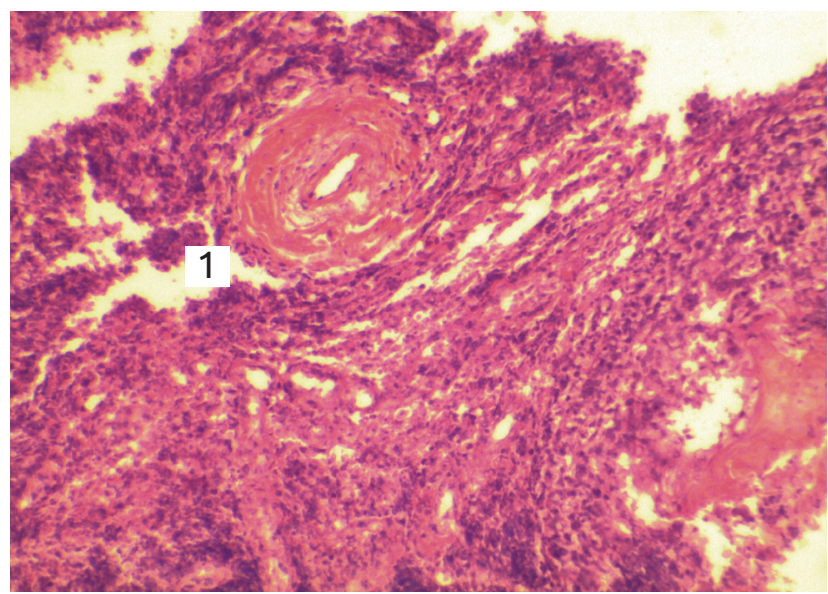

Виражений периваскулярний склероз (1).

Рис. 8. Гістологічний зріз піднебінного мигдалика при співвідношенні апоптоз/некроз у лімфоцитах гомогенату 12,21 (пацієнт № 20). Забарвлення гематоксиліном і еозином. х 180.

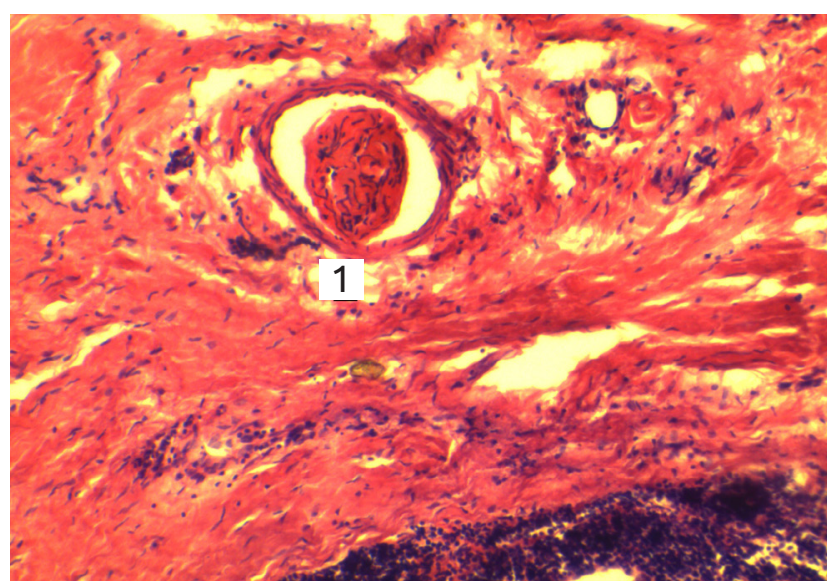

Тромб у просвіті перерозтягнутої артерії в капсулі піднебінного мигдалика (1).

Рис. 9. Гістологічний зріз піднебінного мигдалика при співвідношенні апоптоз/некроз у лімфоцитах гомогенату 11,24 , у крові - 9,01 (пацієнт № 27). Забарвлення гематоксиліном і еозином. $x 180$ зультаті цього IB продовжував знижуватися, сягаючи рівня $(93,64 \pm 3,58)$.

У проміжках між фолікулами, а також на місці самих фолікулів нерідко можна було спостерігати казеозні пробки, сформовані скупченнями білкового детриту. У випадках, коли співвідношення апоптоз/некроз було кратним 10-12 разам, іноді додатково вдавалося виявляти пердіапедезні крововиливи, а також лімфоїдні фолікули із зруйнованими центральними частинами, які обмежувалися скупченнями макрофагів (рис. 10).

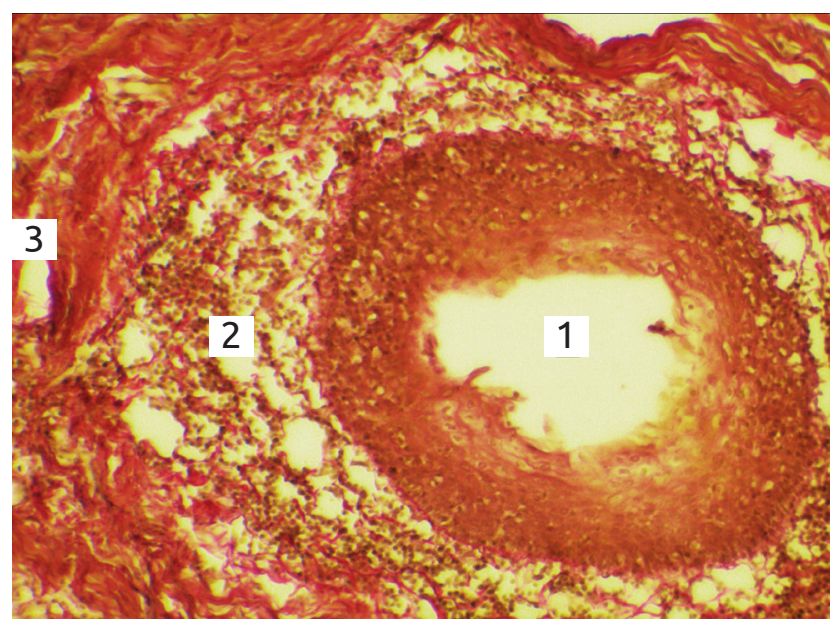

Зруйнована і оточена макрофагами центральна частина лімфоїдного фолікула (1), просвітлення перифолікулярної лімфоїдної тканини (2), проліферація сполучної тканини (3).

Рис. 10. Гістологічний зріз піднебінного мигдалика при співвідношенні апоптоз/некроз у лімфоцитах гомогенату 12,21 (пацієнт № 20). Забарвлення за Вейгертом. x 240.

Отримані дані дають підстави вважати, що при хронічному тонзиліті в лімфоцитах як гемогенату піднебінних мигдаликів, так і в периферійній крові апоптоз переважає над некрозом. Таке переважання характерне для бактерійного ураження мигдаликів, на відміну від вірусного, при якому воно проявляється у нейтрофілах [15]. Причому кратність цього переважання корелює із морфологічними змінами у самих мигдаликах.

По мірі наростання патоморфологічних змін наростає і кратність співвідношення апоптоз/некроз. Так, при співвідношенні, кратному 2-3, патоморфологічна картина була представлена лише помірними судинними реакціями у вигляді посилення васкуляризації із збільшенням кількості та розширенням просвіту дрібних артерій і артеріол з одночасним зниженням пропускної спроможності артерій середнього калібру за рахунок підвищення тонусу їх стінки, що підтверджувалося посиленням звивистості внутрішніх еластичних мембран. Характерним було також підвищення засвоєння слизовою глікогену. Ці явища мають 
Огляди літератури, оригінальні дослідження, погляд на проблему

чисто функціональний характер і $\epsilon$ типовими проявами запального процесу, що, разом із морфологічним станом слизової оболонки, сполучнотканинної капсули і фолікулів дають підстави вважати, що захворювання ще перебуває у стадії компенсації і підлягає консервативному лікуванню.

При співвідношенні апоптоз/некроз кратному 4-6 були зареєстровані судинні зміни дилатаційного характеру, спрямовані на посилення кровонаповнення органного судинного русла, що підтверджується зниженням в артеріях індексу Вогенворта. До них приєднувалися зміни морфологічного характеру у вигляді стоншання слизової оболонки, потовщення сполучнотканинної капсули і зменшення розмірів фолікулів та їх просвітлення, що, разом із явищами метаплазії і гіперкератозу епітелію слизової оболонки, може бути підтвердженням субкомпенсації патологічного процесу; остаточне питання про тактику лікування у таких випадках може бути вирішене при врахуванні даних клінічного обстеження.

Виявлені ж при кратності співвідношення апоптоз/некроз в 7 разів і більше морфологічні зміни у вигляді подальшої деградації епітелію слизової, проліферації сполучної тканини як у капсулі, так і проникнення ії у паренхіму, разом із вираженим периваскулярним склерозом, деструктивними змінами із макрофагальною реакцією у значно зменшених за розмірами лімфоїдних фолікулах, наявністю скупчень білкового детриту та відповідними судинними реакціями є ознаками декомпенсації захворювання і необхідності його оперативного лікування, що збігається із висновками, зробленими на підставі інших морфологічних досліджень $[9,14]$.

Висновки. 1. Співвідношення апоптоз/некроз у лімфоцитах периферійної крові при хронічному тонзиліті $\epsilon$ відображенням такого співвідношення у лімфоцитах піднебінних мигдаликів.

2. При співвідношенні апоптоз/некроз у лімфоцитах гомогенату піднебінних мигдаликів, кратному 2-4, морфологічні зміни у самих мигдаликах відповідають захворюванню у стадії компенсації, при співвідношенні 4-6 за даними морфологічних досліджень процес можна вважати субкомпенсованим і при співвідношенні 7 і більше - декомпенсованим.

3. Метод проточної цитофлуориметрії може бути ефективно використаний як додатковий метод діагностики стадії хронічного тонзиліту і для вирішення питання про тактику його лікування.

Перспективи подальших досліджень. Подальші дослідження дозволять більш ефективно визначати тактику лікування хронічного тонзиліту і встановлювати показання для хірургічного втручання.

\section{ЛІТЕРАТУРА}

1. Автандилов Г. Г. Морфометрия в патологии / Г. Г. Автандилов. - М. : Медицина, 1973. - 246 с.

2. Гаращенко Т. И. Новые подходы к лечению обострений хронического тонзиллита у детей / Т. И. Гаращенко, М. Р. Богомильский, Е.В.Шишмарева // Детские инфекции. - 2004. - № 1. - С. 32-37.

3. Ільїнська І. Ф. Апоптоз, апоцитоз та їх роль в імунній відповіді (аналітичний огляд) / І. Ф. Ільїнська // Ла6. діагностика. - 2002. - № 3. - С. 66-72.

4. Кищук В. В. Исследование связи между состоянием глоточного кольца и развитием патологии в организме. Сообщение 2. Клинико-статистический анализ между состоянием небных миндалин и онкологическими заболеваниями различной локализации // Ж. вушн., носових та горлових хворо6. - 2001. - № 3. - С. 50-53.

5. Кіцера О. Клінічна оториноларингологія / О. Кіцера. - Львів : Видавництво «Кварт», 2007. - С. 310-334.

6. Комплексная терапия у больных до и после тонзиллэктомии / С. В. Андреев, М. С. Чернявская, И. П. Соколова, В.В.Ковтуненко // Матеріали щорічної традиційної осінньої конференції Українського наукового медичного товариства оториноларингологів «Нові технології в оториноларингології». - Журнал вушних, носових і горлових хворо6. - 2012. - № 5-с. - С. 5-6.
7. Лисовская Т. Л. Местное применение препарата "Циклоферон" в профилактике обострений хронического тонзиллита и синусита / Т. Л. Лисовская, С. В. Рязанцев, А. В. Полевщиков // Новости оторинолар. и логопатол. - 2001. - № 3. - С. 107-108.

8. Мельников О. Ф. Роль імунодіагностики у підвищенні лікування хворих на хронічний тонзиліт / О. Ф. Мельников, Д. І. Заболотний // Буковинський медичний вісник. - 2001. - № 2. - С. 115-118.

9. Мельников О. Ф. Современные подходы к консервативной терапии хронического тонзиллита / О. Ф. Мельников, Д. Д. Заболотная. - К. : ООО «Вістка», 2012. - 80 с.

10. Динамика иммунологических показателей и исследование апоптоза лимфоцитов небных миндалин у больных хроническим тонзиллитом на фоне консервативного лечения / А. В. Полевщиков, С. Г. Вахрушев, Е. А. Пожиленкова [и др.] // Вестник оториноларингологии. - 2011. - № 3. - С. 13-17.

11. Потапнев М. П. Апоптоз клеток иммунной системы и его регуляция цитокинами / М. П. Потапнев // Иммунология. - 2002. - № 4. - С. 237-243.

12. Селезнев К. Г. Перитонзиллярный абсцесс нужна ли тонзиллэктомия? / К. Г. Селезнев, П. В. Андреев, А. В. Харьковский // Матеріали щорічної традиційної 
Огляди літератури, оригінальні дослідження, погляд на проблему

осінньої конференції Українського наукового медичного товариства оториноларингологів «Нові технології в оториноларингології». - Журнал вушних, носових і горлових хвороб. - 2012. - № 5-с. - С. 131-132.

13. Факторы врожденного иммунитета в ротоглоточном секрете детей с хроническим тонзиллитом при лечении препаратом лизак / О. Ф. Мельников, Ю. В. Марушко, О. С. Мовчан [и др.] // Матеріали щорічної традиційної осінньої конференції Українського наукового медичного товариства оториноларингологів «Нові технології в оториноларингології» // Журнал вушних, носових і горлових хворо6. - 2012. - № 5-С. - С. 92.

14. Хмельницкая Н. М. Морфофункциональное состояние глоточной и небных миндалин у детей с регионарным лимфаденитом / Н. М. Хмельницкая, А. А. Ланцов, Г. И. Тимофеева // Вестник оториноларингологии. - 2000. - № 3. - С. 31-35.

15. Ярилин А. А. Апоптоз и его роль в целостном организме / А. А. Ярилин // Глаукома. - 2003. - Вып. 2. C. $46-54$.

16. Kitamura K. Pharmacokinetic and clinical evaluation of azithromycin in the pediatric field / K. Kitamura, H. Kamiya, T. Nakano [et al.] // Jpn. J. Antibiot. - 1997. № 50. - P. 206-14.

17. Van Parijs $L$. The roles of costimulation and Fas in T cell apoptosis and peripheral tolerance / L. Van Parijs, A. Ibraghimov, A. K. Abbas // Immunity. - 1996. - Vol. 4. P. 321-328.

\section{REFERENCES}

1. Avtandilov, G.G. (1973). Morfometriya v patologii [Morphometry in pathology]. Moscow: Meditsina [in Russian].

2. Garashchenko, T.I., Bogomilskiy, M.R., \& Shishmareva, Ye.V. (2004). Novyye podkhody k lecheniyu obostreniy khronicheskogo tonzillita u detey [New approaches to the treatment of exacerbations of chronic tonsillitis in children]. Detskiye infektsii - Children's Diseases, (1), 32-37.

3. Ilyinska, I.F. (2002). Apoptoz, apotsytoz ta yikh rol v imunnii vidpovidi (analitychnyi ohliad) [Apoptosis, apocytosis and their role in the immune response (analytical review)]. Lab. Diahnostyka - Laboratory Diagnostics, (3), 66-72 [in Ukrainian].

4. Kishchuk, V.V. (2001). Issledovaniye svyazi mezhdu sostoyaniyem glotochnogo koltsa i razvitiyem patologii v organizme. Soobshcheniye 2 . Kliniko-statisticheskiy analiz mezhdu sostoyaniyem nebnykh mindalinionkologicheskimi zabolevaniyami razlichnoy lokalizatsii [Investigation of the connection between the state of the pharyngeal ring and the development of pathology in the body. Message 2. Clinical and statistical analysis between the state of palatine tonsils and oncological diseases of various locations]. Zh. vushn. nosovykh ta horlovykh khvorob Journal of Ear, Nose and Throat Diseases, 3, 50-53.

5. Kitsera, O. (2007). Klinichna otorynolarynholohiia [Clinical Otolaryngology]. Lviv: Vydavnytstvo "Kvart" [in Ukrainian].

6. Andreyev, S.V., Chernyavskaya, M.S., Sokolova, I.P., Kovtunenko V.V. (2012). Kompleksnaya terapiya u bolnykh do i posle tonzillektomii [Complex therapy in patients before and after tonsillectomy]. Paper, presented at the meeting of Ukrainian Scientific Society of Otorhinolaringologists "New technologies in Otorhinolaryngology". Zhurnal vushn. nosovykh ta horlovykh khvorob - Journal of Ear, Nose and Throat Diseases, 5c, 5-6 [in Russian].

7. Lisovskaya, T.L., Ryazantsev, S.V., \& Polevshchikov, A.V. (2001). Mestnoye primeneniye preparata «Tsikloferon» v profilaktike obostreniy khronicheskogo tonzillita i sinusita [Local application of the drug "Cycloferon" in the prevention of exacerbations of chronic tonsillitis and sinusitis.]. Novosti otorinolaringologii - News of Otorhinolaryngology, (3), 107-108 [in Russian].

8. Melnykov, O.F., Zabolotnyi, D.I. (2001). Rol imunodiahnostyky u pidvyshchenni likuvannia khvorykh na khronichnyi tonzylit [The role of immunodiagnosis in improving the treatment of patients with chronic tonsillitis].
Bukovynskyi medychnyi visnyk - Bukovyna Medical Journal, 2, 115-118 [in Ukrainian].

9. Melnikov, O. F., \& Zabolotnaya, D. D. (2012). Sovremennyye podkhody k konservativnoy terapii khronicheskogo tonzillita [Modern approaches to conservative therapy of chronic tonzilitis]. Kyiv: OOO "Vistka" [in Russian].

10. Polevshchikov, A.V., Vakhrushev, S.G., Mukhomedzyanova, L.V., Pozhilenkova, Ye.A. \& Andriyanova, I.V. (2011). Dinamika immunologicheskikh pokazateley $\mathrm{i}$ issledovaniye apoptoza limfotsitov nebnykh mindalin u bolnykh khronicheskim tonzillitom na fone konservativnogo lecheniya [Dynamics of immunological parameters and study of apoptosis of lymphocytes of palatine tonsils in patients with chronic tonsillitis on the background of conservative treatment]. Vestnik otorinolaringologii - Journal of Otorhinolaryngology, (3), 13-17 [in Russian].

11. Potapnev, M.P. (2002). Apoptoz kletok immunnoy sistemy i yego regulyatsiya tsitokinami [Apoptosis of cells of the immune system and its regulation by cytokines.]. Immunologiya - Immunology, 23 (4), 237-243 [in Russian].

12. Seleznev, K.G., Andreyev, P.V., Kharkovskiy A.V. (2012). Peritonzillyarnyy abstsess - nuzhna li tonzillektomiya? [Peritonsillar abscess - is tonsillectomy necessary?]. Paper, presented at the meeting of Ukrainian Scientific Society of Otorhinolaringologists "New technologies in Otorhinolaryngology". Zhurnal vushnykh, nosovykh i horlovykh khvorob - Journal of Ear, Nose and Throat Diseases, 5c, 131-132 [in Russian].

13. Melnikov, O.F., Marushko, Yu.V., \& Movchan O.S. (2012). Faktory vrozhdennogo immuniteta v rotoglotochnom sekrete detey s khronicheskim tonzillitom pri lechenii preparatom lizak [Factors of congenital immunity in the oropharyngeal secretion of children with chronic tonsillitis in the treatment with the drug lizak]. Paper, presented at the meeting of Ukrainian Scientific Society of Otorhinolaringologists "New technologies in Otorhinolaryngology". Zhurnal vushnykh, nosovykh i horlovykh khvorob-Journal of Ear, Nose and Throat Diseases, 5c, 92 [in Russian].

14. Khmelnitskaya, L.M., Lantsov, A.A., \& Timofeyeva, G.N. (2000). Morfofunktsionalnoye sostoyaniye glotochnoy i nebnykh mindalin u detey s regionarnym limfadenitom [Morphofunctional state of pharyngeal and palatine tonsils in children with regional lymphadenitis.]. Vestn. Otorinolar. - Journal of Otorhinolaryngology (3), 31-36 [in Russian]. 
Огляди літератури, оригінальні дослідження, погляд на проблему

15. Yarilin, A.A. (2003). Apoptoz i yego rol v tselostnom organizme [Apoptosis and its role in the whole organism.]. Glaukoma - Glaucoma, 2, 46-54 [in Russian].

16. Kitamura, K., Kamiya, H., Nakano, T., \& Sakurai, M. (1997). Pharmacokinetic and clinical evaluation of

azithromycin in the pediatric field. The Japanese journal of antibiotics, 50 (2), 206-214.

17. Van Parijs, L., Ibraghimov, A., \& Abbas, A.K. (1996). The roles of costimulation and Fas in T cell apoptosis and peripheral tolerance. Immunity, 4 (3), 321-328.

\title{
ХАРАКТЕР И ОСОБЕННОСТИ МОРФОЛОГИЧЕСКИХ ИЗМЕНЕНИЙ В НЕБНЫХ МИНДАЛИНАХ У БОЛЬНЫХ ХРОНИЧЕСКИМ ТОНЗИЛЛИТОМ В ЗАВИСИМОСТИ ОТ УРОВНЯ АПОПТОЗА ЛИМФОЦИТОВ
}

\author{
ОМ. И. Герасимюк, А. И. Яшан \\ ГВУз «Тернопольский государственный медицинский университет имени И. Я. Горбачевского Мз Украины»
}

РЕЗЮМЕ. При сопоставлении состояния апоптоза и некроза в лимфоцитах небных миндалин и периферической крови по результатам морфологических исследований у больных хроническим тонзиллитом установлена зависимость морфологических изменений от состояния апоптоза.

Цель исследования - установить уровень апоптоза и его соотношение с некрозом в лимфоцитах и нейтрофилах гомогената небных миндалин и в периферической крови больных хроническим тонзиллитом и сопоставить полученные данные с результатами морфологических исследований.

Материал и методы. Проведено обследование больных хроническим тонзиллитом после тонзиллэктомии с определением состояния апоптоза и некроза в лимфоцитах и нейтрофилах гомогената небной миндалины и в периферической крови на проточном цитофлуориметре. Кроме того, всем пациентам проводилось морфологическое исследование удаленных небных миндалин.

Результаты. При хроническом тонзиллите в лимфоцитах апоптоз преобладает над некрозом. Такое прео6ладание характерно для бактериального поражения миндалин, в отличие от вирусного, при котором оно проявляется в нейтрофилах. Причем кратность этого преобладания коррелирует с морфологическими изменениями в самых миндалинах. По мере нарастания патоморфологических изменений нарастает и кратность соотношения апоптоз/некроз. При соотношении, кратном 2-3, патоморфологическая картина представлена лишь умеренными сосудистыми реакциями в виде усиления васкуляризации с увеличением количества и расширением просвета мелких артерий и артериол с одновременным снижением пропускной способности артерий среднего калибра. Это, вместе с морфологическим состоянием слизистой оболочки, соединительнотканной капсулы и фолликулов дает основания считать, что заболевание еще находится в стадии компенсации и подлежит консервативному лечению. При соотношении апоптоз/некроз кратном 4-6 были зарегистрированы сосудистые изменения дилатационного характера. К ним присоединялись морфологические изменения в виде истончения слизистой оболочки, утолщения соединительнотканной капсулы и уменьшения размеров фолликулов с их просветлением, что, вместе с явлениями метаплазии и гиперкератоза эпителия слизистой оболочки, может быть подтверждением субкомпенсации патологического процесса.

Обнаруженные при кратности соотношения апоптоз / некроз в 7 раз и более морфологические изменения в виде дальнейшей деградации эпителия слизистой, пролиферации соединительной ткани как в капсуле, так и проникновение ее в паренхиму вместе с выраженным периваскулярным склерозом, деструктивными изменениями с макрофагальной реакцией в значительно уменьшенных по размерам лимфоидных фолликулах, наличием скоплений белкового детрита и соответствующими сосудистыми реакциями являются признаками декомпенсации заболевания и необходимости его оперативного лечения.

Выводы. При соотношении апоптоз/некроз в лимфоцитах гомогената небных миндалин и периферической крови кратном 2-4 морфологические изменения в самых миндалинах соответствуют заболеванию в стадии компенсации, при соотношении 4-6 по данным морфологических исследований процесс можно считать субкомпенсированным и при соотношении 7 и более - декомпенсированным.

КЛЮЧЕВЫЕ СЛОВА: тонзиллит; апоптоз; эпителий; метаплазия; склероз.

\section{CHARACTER AND PECULIARITIES OF MORPHOLOGICAL CHANGES IN PALATINE TONSILS IN PATIENTS WITH CHRONIC TONSILLITIS DEPENDING ON THE LEVEL OF APPOTHOSIS OF LYMPHOCYTES}

\section{Horbachevsky Ternopil State Medical University}

@M. I. Herasymiuk, O. I. Yashan

SUMMARY. When comparing the state of apoptosis and necrosis in lymphocytes of palatine tonsils and peripheral blood by morphological researches results in patients with chronic tonsillitis we established the dependence of morphological changes from the state of apoptosis. 
Огляди літератури, оригінальні дослідження, погляд на проблему

The aim of the study - to set the level of apoptosis and its relation with necrosis in the lymphocytes and neutrophils of the palatine tonsils homogenate and in the peripheral blood of patients with chronic tonsillitis and to compare the obtained data with the results of morphological studies.

Materials and Methods. The examination of patients with chronic tonsillitis after tonsillectomy with the definition of the state of apoptosis and necrosis in lymphocytes and neutrophils of the homogenate of the palatine tonsils and in peripheral blood on flow cytofluorometer was performed. In addition, all patients underwent morphological examination of removed palatine tonsils.

Results and Discussion. When chronic tonsillitis in lymphocytes apoptosis prevails over necrosis. This predominance is characteristic for bacterial damage of the tonsils, unlike the viral, where it is manifested in neutrophils. And the multiplicity of this predominance correlates with morphological changes in the tonsils itself. As the pathomorphological changes increase, multiplicity also increases ratio of apoptosis/necrosis. So, at a ratio of $2-3$ times the pathomorphological picture is represented only by moderate vascular reactions in the form of increased vascularization with an increase in the number and enlargement of the lumen of small arteries and arterioles with simultaneous decrease bandwidth of arteries of medium caliber. This is along with the morphological state of the mucous membrane, connective tissue capsule and follicles gives reasons to believe that the disease is still in the stage of compensation and subject to conservative treatment. At a ratio of apoptosis/necrosis 4-6 were registered vascular changes of a divination nature. They were joined by morphological changes in the form of thickening of the mucous membrane, thickening of connective tissue capsule and decrease the size of the follicles and their enlightenment, which together with the phenomena of metaplasia and hyperkeratosis of the epithelium of the mucous membrane can be a confirmation of subcompensation of the pathological process. Detected with the multiplicity of the ratio of apoptosis/necrosis in 7 times and more morphological changes in the form of further degradation of the epithelium of the mucosa, proliferation of the connective tissue both in the capsule and its penetration into parenchyma with pronounced perivascular sclerosis, destructive changes with a macrophage reaction in considerably reduced in size lymphoid follicles, and the presence of clusters of protein detritus and the corresponding vascular reactions are the signs of decompensation of the disease and the need for its surgical treatment.

Conclusions. At a ratio of apoptosis/necrosis in lymphocytes of a homogenate of palatine tonsils and peripheral blood equal 2-4 the morphological changes in the tonsils themselves correspond to the disease in the stage of compensation, at a ratio of 4-6 according to morphological studies, the process can be considered as subcompensated and at a ratio of 7 and more - decompensated.

KEY WORDS: tonsillitis; apoptosis; epithelium; metaplasia; sclerosis. 